\title{
EARLY INDICATIONS OF THE BIBLE'S PLACE IN PUBLIC MORALITY: THE BATLHAPING, WILLIAM BURCHELL AND THE BIBLE
}

\author{
Gerald West \\ School of Theology \\ University of Natal
}

\begin{abstract}
William Burchell, the intrepid English explorer was one of the first travellers to bring a Bible among the Tlhaping people of southern Africa. Through a careful, close and cross-grained reading of Burchell's account of his visit among the Tlhaping, I reflect on an emerging trajectory of the Bible's place in public morality in South Africa. Though the focus of my paper is historical hermeneutics attempting to analyse the foundational apprehensions that constitute what may be called a neo-indigenous biblical hermeneutic - the paper will also briefly explore the more modern territory of the Bible in contemporary "new" South African morality. In other words, the latter part of the paper will try to make sense of our present moment in which the Bible as a resource for public morality seems to be trapped between its neo-indigenous hermeneutical heritage and its neo-liberal future.
\end{abstract}

\section{Introduction: accessible silos for public morality}

More than a decade ago, Takatso Mofokeng delineated the dilemma confronting black South Africans in their relationships with the Bible as follows: the Bible both occupies a central position "in the ongoing process of colonization, national oppression and exploitation" (Mofokeng 1988:34) and the Bible has been accepted by black Christians, for when many Black Christians read their history of struggle carefully, they come upon many Black heroes and heroines who were inspired and sustained by some passages and stories of the Bible in their struggle, when they read and interpreted them in the light of their Black experience, history and culture. They could consequently resist dehumanization and the destruction of their faith in God the liberator. It is this noble Black Christian history that helps to bring out the other side of the Bible, namely, the nature of the Bible as a book of hope for the downtrodden (Mofokeng 1988:38).

While Mofokeng concedes that this latter response has a certain amount of validity, he wants to insist that there are numerous "texts, stories and traditions in the Bible which lend themselves to only oppressive interpretations and oppressive uses because of their inherent oppressive nature." What is more, he continues, any attempt "to 'save' or 'co-opt' these oppressive texts for the oppressed only serve the interests of the oppressors" (Mofokeng 1988:37-38). Recognising this, Mofokeng seems to argue, young blacks "have categorically identified the Bible as an oppressive document by its very nature and to its very core" and suggest that the best option "is to disavow the Christian faith and consequently be rid of the obnoxious Bible." Indeed, some "have zealously campaigned for its expulsion from the oppressed Black community," but, he notes, with little success (Mofokeng 1988:40).

Unfortunately, Mofokeng does not offer further reflection on those who would "be rid 
of the obnoxious Bible;" instead he focuses on the reason for their lack of success, which, he argues, is largely due to the fact that no easily accessible ideological silo or storeroom is being offered to the social classes of our people that are desperately in need of liberation. African traditional religions are too far behind most blacks while Marxism, is to my mind, far ahead of many blacks, especially adult people. In the absence of a better storeroom of ideological and spiritual food, the Christian religion and the Bible will continue for an undeterminable period of time to be the haven of the Black masses par excellence.

Given this situation of very limited ideological options, Mofokeng continues, "Black theologians who are committed to the struggle for liberation and are organically connected to the struggling Christian people, have chosen to honestly do their best to shape the Bible into a formidable weapon in the hands of the oppressed instead of leaving it to confuse, frustrate or even destroy our people" (Mofokeng 1988:40).

To summarize, Mofokeng's argument goes like this. The Bible comes to Africans as an “ideological instrument of colonization, oppression and exploitation"(Mofokeng 1988:34). However, this historical trajectory is countered by another, a trajectory in which generations of black Bible "readers" have found resources in the Bible for their struggle for liberation and life. But, while there clearly are texts that do serve the ideological agenda of liberation, there are others that undermine and subvert these very struggles. In fact, Mofokeng suggests, so much of the Bible is inherently oppressive that it may be best, as young black South Africans have indeed argued, to get rid of this "obnoxious Bible." However, the argument continues, for most black South Africans the Bible is a more accessible silo than other contenders, and so remains an important storeroom in which ideological and spiritual food may be found. Finally, the argument concludes, given this reality, black theologians are required to serve ordinary black Christians by taking this silo seriously.

Although acknowledging that the Bible does have some substantive value for liberation and life, the overall thrust of Mofokeng's argument is that the Bible's primary value lies in its accessibility to ordinary African Christians. In other words, the Bible's minimal intrinsic value becomes significant for pragmatic reasons - it is accessible. The implication of Mofokeng's argument here, however, is that there may be other silos which have more intrinsic value (though they may be less pragmatically accessible). The two alternative silos he identifies are African Traditional Religions and Marxism. The former, he claims, is "too far behind most blacks" while Marxism is, in his opinion "far ahead of many blacks, especially adult people" (Mofokeng 1988:40). While Mofokeng clearly implies that these silos have more to offer than the Bible, both are inaccessible, though for different reasons. While I hesitate to exegete Mofokeng's assessment of their inaccessibility, he seems to be saying that both African Traditional Religions and Marxism are historically, emotionally, and symbolically less accessible than the Bible. Furthermore, his spatial language suggests a sense of progression, in that most ordinary African Christians have moved on from African Traditional Religions to the Bible, but have not yet moved on from the Bible to Marxism.

Here, then, are three contenders for a role in forming our public morality in South Africa: the Bible, African Traditional Religions, and Marxism. More than ten years after Mofokeng reflected on the place of the Bible in black liberation, I want to reflect on the place of the Bible in South African public morality post-liberation.

\section{The Bible: substantive or instrumentalist resource?}

Given Mokokeng's analysis, the question that now requires to be asked is whether his analysis still holds, a decade later. Much has changed. Marxism, while having been somewhat discredited elsewhere in the world, is making something of a comeback in South Africa as 
insidious neo-liberal economics and rampant globalisation increase their grip on our government, who many feel have now abandoned any remaining vestiges of their African socialist heritage by turning away from the RDP (Reconstruction and Development Programme) to GEAR (Growth, Employment and Redistribution) as an economic policy framework. And, as some have said, even NEPAD (New Partnership for Africa's Development), a South African driven vision for the African continent, is just GEAR for Africa. So there is plenty of space in South Africa at present for a recovery of certain elements of Marxism, and there are clear signs that South African trade unions and the South African Communist Party are taking up this space.

The resurgence and recovery of African Traditional Religions is unmistakable post1994, whether in its public form of the African Renaissance or in its multitude of more private variations. In a process that began publically, I would suggest, with a conference in Grahamstown in $1985,{ }^{1}$ African Traditional Religions, particularly as they are manifest in African Independent/Indigenous/Initiated Churches, have been slowly regaining the ground that they had lost through the analysis of Black Theology in the 1970s and early 1980s. In fact, it might be argued, and indeed has been argued (Masipa 1997), that African Traditional Religions have always been the default ideological silo for African Christians, with the emphasis on the term "African" in this phrase. Christianity, including the Bible, it could be argued, is the public transcript, in the sense invoked by James Scott (Scott 1990), that Africans have been forced to engage with in order to survive. Contra Antonio Gramsci, Scott believes that "the historical evidence clearly shows that subordinate groups have been capable of revolutionary thought that repudiates existing forms of domination."

However, because the occasions on which subordinate groups have been able to act openly and fully on that thought are rare, the conflict will usually take "a dialogic form in which the language of the dialogue will invariably borrow heavily from the terms of the dominant ideology prevailing in the public transcript." The dominant discourse becomes, then, "a plastic idiom or dialect that is capable of carrying an enormous variety of meanings, including those that are subversive of their use as intended by the dominant," for in most contexts of domination "the terrain of dominant discourse is the only plausible arena of struggle." So by recognizing that adopting and adapting the dominant discourse is a guise induced by power relations that is necessary outside of the safety of the hidden transcript, and by learning to read the dialects and codes generated by the techniques and arts of resistance, we can discern a dialogue with power in the public transcript (Scott 1990:101-103, 138).

So instead of focussing on the public transcript - in this case Christianity, which represents the formal relations between the powerful and weak - as most social analysis does, we should attempt to "read, interpret, and understand the often fugitive political conduct of subordinate groups" - the hidden transcript (Scott 1990:xii; Comaroff 1985:261). "The hidden transcript" is the discourse, including speech acts and a whole range of other practices, that subordinate groups create in response to their ordeal of domination - a discourse "that represents a critique of power spoken behind the back of the dominant." Behind the scenes, subordinate groups "create and defend a social space in which offstage dissent to the official transcript of power relations may be voiced." The practices and rituals of denigration and domination routinely generated by slavery, serfdom, the caste system, colonialism, patriarchy, and racism usually deny subordinates the ordinary

1. The conference was the "Forum on Christianity in the Southern African Context," held at Rhodes University, Grahamstown, at the end of January 1985 (see de Gruchy 1985, 1985; Tlhagale 1985; Chikane 1985; Scofield 1985). 
response of asserting their dignity through negative reciprocity: a slap for a slap, an insult for an insult (Scott 1990:xi-xii). Instead, subordinates establish their dignity, register their resistance, and elaborate their hidden transcript in a restricted "public" or social circle that excludes - that is hidden from - certain specified sectors.

The hidden transcript represents the safe articulation and acting out of forms of resistance and defiance that is usually thwarted in contexts where the exercise of power is nearly constant. "Discretion in the face of power requires that a part of the 'self' that would reply or strike back must lie low. It is this self that finds expression in the safer realm of the hidden transcript." The hidden transcript speaks what must normally be choked back and takes back the speech or behaviour that seemed unavoidable and was required for survival in power-laden encounters with the dominant (Scott 1990:18, see also 14-115). The crucial point of Scott's detailed argument is that "the hidden transcript is a self-disclosure that power relations normally exclude from the official transcript" (Scott 1990:113-115). The public transcript - the open interaction between subordinates and those who dominate where it is not positively misleading, is unlikely to tell the whole story about power relations, because it is frequently in the interest of both parties to tacitly conspire in misrepresentation (Scott 1990:2).

A focus on "a partly sanitized, ambiguous, and coded version of the hidden transcript" in this case forms of African Traditional Religions - that is always present in the public discourse of subordinate groups in the form of rumours, gossip, folktales, songs, gestures, jokes, theatre, and other forms of popular culture and religion, reveals forms of resistance, defiance, and an alternative consciousness (Scott 1990:19). So, in this analysis, the term "African Christian" may not signal a unity, but a clever conjunction of the hidden and public in one phrase.

Similarly, Tinyiko Maluleke argues that the present, third, phase of South African Black Theology, must re-evaluate the place of Christianity (and the Bible) in the lived reality of ordinary black South Africans. The contours of the third phase are difficult to discern, says Maluleke, because "we are living in and through it" (Maluleke 1998:61). Nevertheless, he does offer a tentative sketch of the third phase. Repudiating allegations of Black Theology's demise, Maluleke argues that the third phase of Black Theology draws deeply on resources within earlier phases of Black Theology, and elaborates these formative impulses into the future.

First, while the plurality of ideological positions and political strategies in the construction of Black Theology has been acknowledged since the early 1980s, the ideological and political plurality within Black Theology in the 1990s is more marked and brings with it a new 1990s temptation that must be refused. ${ }^{2}$ Ideological and political plurality in postapartheid (and post-colonial) ${ }^{3}$ South Africa must avoid both the temptation of an uncommitted play with pluralism and the temptation of a despairing paralysis (perhaps even an abandonment) of commitment. Despite the pressures of ideological and political plurality, commitment remains the first act in Black Theology, whatever the particular brand (61).

Second, if race was the central category in the first phase of Black Theology, and if the category of class was placed alongside it in the second phase of Black Theology, then

2. The paper of Maluleke I am referring to here is a brief "concept paper," and so I am sometimes making fairly bold inferences from the available clues. Wherever possible, I have used Maluleke's other published work to enhance my understanding of the moves he makes in the concept paper.

3. Talk of the "post-colonial" has been slow to find a foothold in the fields of theology and biblical studies in South Africa (and indeed to the north of us); the reasons for this deserve some attention (see West 1997; Dube 1996, 1997, 1999, 2000). 
gender as a significant category has joined them in the third phase of Black Theology. But, once again, the tendency to minimise the foundational feature of Black Theology, namely, race, must be resisted. Gender, like class, in South Africa always has a racial component. Furthermore, warns Maluleke, in a context "where race is no longer supposed to matter" (61), racism often takes on different guises and becomes "more "sophisticated" " (62).

The third and final feature of phase three Black Theology has three related prongs, each of which might be considered as a separate element. Here, however, I want to stress their connectedness, as does Maluleke, and so will treat them as sub-elements of a formative feature of the third phase of South African Black Theology. The formative feature of phase three Black Theology is the identification of African Traditional Religions (ATRs) and African Independent/Instituted/Initiated Churches (AICs) as "significant" (perhaps even primary?) dialogue partners (62). ${ }^{4}$

Subsumed under this general feature, the first of the three prongs has to do with culture. Whereas phase one Black theology "ventured somewhat into cultural ... issues," phase two "became more and more concerned with the struggle of black people against racist, political and economic oppression" (Maluleke 1998:133). However, “At crucial moments connections with African culture would be made - provided that culture was understood as a site of struggle rather than a fixed set of rules and behaviours" (133). Culture remains problematised in phase three, but the envisaged rapprochement with ATRs and AICs that characterises phase three foregrounds culture in a form not found in phase two.

The second prong has to do with solidarity with the poor. In each of its phases, Black Theology "has sought to place a high premium on solidarity with the poor and not with the state or its organs - however democratic and benevolent such a state might be." While such a position "must not be mistaken with a sheer anti-state stance ... Black Theology is first and foremost not about the powerful but about the powerless and the silenced." And, and I stress this conjunction, "serious interest" in ATRs and AICs affords Black Theology in phase three "another chance of demonstrating solidarity with the poor - for ATRs is [sic] the religion of the poor in this country" (Maluleke 1998:62).

Closely related to the first and second prong, but particularly to the first, is a third. By making culture a site of struggle, Black Theology "managed to relativise the Christian religion sufficiently enough to encourage dialogue not only with ATRs but with past and present struggles in which religions helped people to take part, either in acquiescence or in resistance" (133). If, as Mosala has argued (Mosala 1986), African culture can be a primary site of a hermeneutics of struggle for African Theology, supplemented only with a political class-based hermeneutics, then Christianity is not a necessary component in a Black Theology of liberation (Maluleke 1998:133). A key question, therefore, for the third phase of South African Black Theology is, "Have black and African theologies made the necessary epistemological break from orthodox or classical Christian theology required to effect 'a creative re-appropriation of traditional African religions' (Mosala 1986: 100)?” (135).

Speaking to his own question, Maluleke argues that South African Black Theology has

4. Implicit in this formulation is my tentative analysis that locates ATRs and AICs along a continuum. At one end of the continuum would be ATR as a distinct "faith." I am not sure what would stand at the other end of the continuum, but along the way would be various manifestations of what we call AICs, gradually becoming less and less (primally) African. My play on "primal" here is deliberate, alluding to the "translation" (see Maluleke 1996) trajectory in African theology articulated by Lamin Sanneh (Sanneh 1989) and Kwame Bediako (Bediako 1995) and the high place it accords ATR as primal religion.

5. Implicit here is a period of emergence of phase three Black Theology which includes the context of a postapartheid state; Maluleke would not use this formulation to address the relationship between Black Theology and the apartheid state. 
tended to use "classical Christian tools, doctrines and instruments - for example the Bible and Christology" pragmatically. Black Theology has used Christianity to "get the land back and get the land back without losing the Bible" (Mosala 1987:194).

Realising that Christianity and the Bible continue to be a "haven of the Black masses" (Mofokeng 1988:40), black theologians reckoned that it would not be advisable simply "to disavow the Christian faith and consequently be rid of the obnoxious Bible." Instead the Bible and the Christian faith should be shaped "into a formidable weapon in the hands of the oppressed instead of just leaving it to confuse, frustrate or even destroy our people" (Mofokeng 1988:40). Preoccupation with Christian doctrines and ideas was, for black theology therefore, not primarily on account of faith or orthodoxy considerations, but on account of Christianity's apparent appeal to the black masses (Maluleke 1998:134).

Given this analysis, Maluleke goes on to argue,

What needs to be re-examined now [in phase three] however, is the extent to which the alleged popularity of Christianity assumed in South African black theology is indeed an accurate assessment of the religious state of black people. If it were to be shown that ATRs are as popular as Christianity among black South Africans then in not having given much concerted attention to them, black theology might have overlooked an important resource. There is now space for this to be corrected by making use of alternative approaches (Maluleke 1998:134).

As I have shown, via Maluleke's analysis, one of the important features of phase three Black Theology is the recognition, recovery, and revival of its links with ATRs and AICs, and in so doing renewing its dialogue with African Theology in its many and various forms. ${ }^{6}$ In other words, Maluleke could be said to be revisiting and questioning Mofokeng's assertion that "African traditional religions are too far behind most blacks" (Mofokeng 1988:40). Is this actually the case, asks Maluleke? Gabriel Setiloane asks the question even more starkly: "Why do we continue to seek to convert to Christianity the devotees of African traditional religion?" (Setiloane 1977:64, cited in Maluleke 1997:13). "This," says Maluleke, "is a crucial question for all African theologies [including South African Black Theology] as we move into the twenty-first century" (13).

Alongside this question, of course, looms the related question, prompted by Maluleke's analysis, of whether Black Theology can be done without the Bible. ${ }^{7}$ If it is true, as is claimed by both Mofokeng and Mosala, that the Bible is primarily of strategic, not substantive (see Cady 1986, and West 1995:1-3-130), importance to Black Theology, a claim that is vigorously rejected by Desmond Tutu (see Tutu 1983), Allan Boesak (see Boesak 1984), Simon Maimela (Maimela 1991), and many other Black theologians, then there are good grounds for a Black Theology without "the Book."

However, Maluleke, like Mofokeng, doubts whether "pragmatic and moral arguments can be constructed in a manner that will speak to masses without having to deal with the Bible in the process of such constructions" (Maluleke 1996:14). The Bible remains in the 1990s, and probably into the millennium, "a "haven of the Black masses"” (14). And as long as it is a resource, it must be confronted, "precisely at a hermeneutical level" (14). Quite what Maluleke means by this is not yet clear, but he does offer some clues, which

6. Each of Maluleke's publications cited articulates forms of a dialogue between Black Theology and its three related interlocutors: ATRs, AICs, and African Theologies.

7. Randall Bailey puts the question slightly differently, but in a closely related sense, when he argues "that unless one is aware of one's own cultural biases and interests in reading the text and appropriating the tradition, one may be seduced into adopting another culture, one which is diametrically opposed to one's own health and well-being" (Bailey 1998). 
emerge in his dialogue with the biblical hermeneutics of African Theology (Maluleke 1997:14-16).

He agrees with Mercy Amba Oduyoye, who speaks with many African women, ${ }^{8}$ when she says that the problem with the Bible in Africa is that "throughout Africa, the Bible has been and continues to be absolutized: it is one of the oracles that we consult for instant solutions and responses" (Oduyoye 1995:174, cited in Maluleke 1997:15). "However," continues Maluleke, while many African biblical scholars and theologians are locked into a biblical hermeneutics that makes "exaggerated connections between the Bible and African heritage," "on the whole, and in practice, [ordinary] African Christians are far more innovative and subversive in their appropriation of the Bible than they appear" (Maluleke 1997:14-15). Though they "may mouth the Bible-is-equal-to-the-Word-of-God formula, they are actually creatively pragmatic and selective in their use of the Bible so that the Bible may enhance rather than frustrate their life struggles" (Maluleke 1996:13). The task before Black Theology, then, is "not only to develop creative Biblical hermeneutic methods, but also to observe and analyse the manner in which African Christians 'read' and view the Bible" (15).

Indeed, an important task confronting Black and African theologies in South Africa is "to observe and analyse the manner in which African Christians 'read' and view the Bible." As the work of Mofokeng and Mosala has hinted, ordinary black South Africans have adopted a variety of strategies in dealing with an ambiguous Bible, including rejecting it (Mofokeng 1988:40) and strategically appropriating it as a site of struggle (Mosala 1986:184; Mofokeng 1988:41). But, as I have argued (West 1999:88-89), neither Mofokeng nor Mosala provide the kind of detail required for Maluleke's project. Even my own attempts to reflect on and conjure concepts that elucidate the way in which ordinary black South Africans "read" the Bible are not detailed enough (West 1999:89-107), and my cursory comments on how black Christians "view" the Bible are equally inadequate (West 2000:47-49).

We African biblical scholars, all of us, assume that the Bible is central to the lived faith of ordinary African Christians. As we have noted, it is commonly assumed, even argued, by Black and African biblical scholars and theologians that the Bible is a significant resource for African Christians (see Mbiti 1977; Tutu 1983:124-129). Maluleke himself acknowledges this, pointing to the many ways in which the Bible is a resource in Africa: as the most widely translated book it makes a contribution to the construction of indigenous grammars and texts, it is a basic textbook in primary and higher education, literacy has been closely tied to Bible reading and memorization, it is the most accessible basic vernacular literature text, a storybook, a compilation of novels and short stories, a book of prose and poetry, a book of spiritual devotion (i.e. the "Word of God") as well as a "science" book that "explains" the origins of all creatures. In some parts of Africa, the dead are buried with the Bible on their chests, and the Bible is buried into the concrete foundations on which new houses are to be built. In many African Independent Churches it is the physical contact between the sick and the Bible that is believed to hasten healing (Maluleke 2000:91-92).

Clearly African Christians relate to the Bible in various ways, and this is Maluleke's point - and one of the central strands of my argument in this article - that we recognize the diverse ways in which ordinary Africans actually engage with the Bible. In fact, Maluleke goes further, insisting that we probe beneath the apparent place of the Bible in the lives of ordinary indigenous Africans. Leaning on the work of those Black theologians who have

8. See for example (Dube 1997; Mbuwayesango 1997; Masenya 1997; Sibeko and Haddad 1997).

9. I am in the process of producing a series of publications that attempt to be more precise (see for example West Forthcoming). 
gone before him, particularly Mosala and Mofokeng, Maluleke asks us to re-examine the relationship between black Africans and the Bible, for (and here Maluleke is using Scott's terminology) "the massive public displays of African 'attachment' to the Bible must not be taken only at face value. Both Christianity and the Bible may not, in and of themselves, be as important for Africans as it may appear" (Maluleke 2000:69).

It is not only Maluleke who leans on those Black theologians who have gone before him; I too, a white South African, have only found my way in the field of South African biblical hermeneutics because of the profound legacies left by early generations and current proponents of South African Black Theology. ${ }^{10}$ But significant as the contributions of Black Theology have been over the past thirty years, the ancestors of Black Theology lie further back, as Maluleke's recent work on the importance of ATRs and AICs suggests. In fact, Maluleke's recent studies have played an important role in pushing my own work back into the past.

We have been right to concentrate, as Maluleke's formulation indicates, on the present, placing our focus on an observation and analysis of "the manner in which African Christians 'read' and view the Bible." Now, perhaps, is an appropriate time to follow Maluleke's gaze to the past, to the interpretative ancestors of Black Theology. We cannot do justice to Maluleke's task, I would argue, unless we also observe and analyse the manner in which indigenous Africans, both before and after "Christianity," have "read" and have viewed the Bible. Implicit in Maluleke's summoning of (or being summoned by) African Traditional Religion(s) and the African Independent Churches, is the pull of the past, and a comprehensive interpretative history of the Bible in southern Africa.

\section{Towards an interpretative history of the Bible in Southern Africa}

Such an interpretative history is a daunting task, but if we are to avoid a prescriptive approach to the Bible place's in the South African public realm, then we must take up this descriptive task. The task would, in my view, consist of multiple case studies of particular communities and sectors, and would trace the Bible's presence from its arrival with the missionary and colonial agents who first brought it to southern Africa, through the earliest encounters between this book and indigenous a particular indigenous people, focussing initially on the perception and reception of the Bible as an untranslated non-indigenous object, but a translation nevertheless in the hands of those who bring it, surrounded by a host of meanings and collocations, most of them European in origin but gradually gathering new indigenous (unintended) meanings and collocations. This first phase of reception would merge with a second, in which the Bible has been translated, or parts of it, from languages not necessary indigenous to the text or the first translators, and would continue through the emergence of the initial wave of indigenous "converts" who worked with the Bible in their language, both taking up missionary meanings and contributing their own, until the tracks of the Bible in southern Africa diverge into two related paths, one dominated by African biblical scholars and the other by ordinary African "readers" of the Bible in local churches and communities. All of which would bring us to the present, though the route in each case would be different.

10. In my opinion, there is much work still to be done by South African Black Theology; the foundations laid by the past thirty years of Black Theology are deep and fertile, and we ignore them at our peril. We certainly have to go forward, but we are foolish if we imagine that we can do this without constantly returning to these important fonts. We may move beyond them, but they must remain to shape where and how we go forward.

11. I use inverted commas as a reminder that my problematising of the place of the Bible in Africans' appropriation of the missionary package may turn out to pose important questions about any unitary understanding of Christianity. 


\section{The Bible as an object of strange power}

So follow me as I take up the beginning of the first phase of this task by examining the arrival and reception of the Bible among the BaTlhaping people of southern Africa. ${ }^{12}$ In the beginning the Bible was there. In this, the first protracted encounter between Christian missionaries and the Thaping people of southern Africa, the Bible is palpably present. Stating this may seem rather mundane; of course the Bible is present in the missionary enterprise! We would be surprised if it were not. True, but given its foundational presence, it does disappear remarkably quickly from the analytical gaze of current criticism in its various historical, anthropological, political and literary guises.

While I would not want to lean too heavily on the adjective "foundational" above, there are grounds for using a formulation like this in discussing the role and presence of the Bible in early missionary encounters in southern Africa. First, it is there in the beginning, along with the guns, beads, ox wagons, ploughs, watches, mirrors, telescopes, letters, tobacco and other items brought by the missionaries. Second, there are signs that the Bible is perceived by indigenous peoples, at least in southern Africa, as an object of power more like the gun than, say, a utilitarian object like the candle. Third, even in these pre-literate days the Bible begins to be appropriated via a range of interpretative moves yet to be documented and analysed, laying a hermeneutical foundation for successive generations of African interpreters in a context (like South Africa) in which what we have done and what we do with the Bible really does matter.

What the missionaries failed to notice - among their many misrecognitions - was "that the attraction of whites to the Tlhaping flowed from the mystical qualities attributed to them and their things in a hinterland where raids were endemic and where guns, beads, and tobacco had become prime valuables" (Comaroff and Comaroff 1991:179). Among the "goods of strange power" (Comaroff and Comaroff 1991:182) associated with the arrival of whites in their land was the Bible. However, in studies on the encounter between missionaries and/as colonial agents, including studies on the specific encounter between the non-conformist missionaries and the Southern Tswana - the focus of this article - the Bible tends to be subsumed and assumed under terms like "Christianity," "the message," "the Word," etc. (Comaroff 1985; Comaroff and Comaroff 1991; Comaroff and Comaroff 1997; Landau 1995). Clearly, the Bible is part of the missionary-colonial package in that it is integral to most if not all forms of Christianity and colonial activity, particularly the nonconformist forms that were propagated amongst the Tlhaping. Here I will argue that a case can be made for treating the Bible as a separable object of strange power that may have been apprehended by the Tlhaping in ways quite different from its collocations within the missionary-colonial package in which it came. ${ }^{13}$

As I have indicated, objects in the encounter between the Tlhaping and missionaries were charged with power. Indeed, in the earliest encounters "The Tlhaping seem to have related to the Europeans as objects, touching and bearing in on them, enjoying a closeness never again permitted by the etiquette of the mission, with its deference to racial separation and the spatial discreteness of person and property" (Comaroff and Comaroff 1991:182).

12. In my title and this first reference I have retained the prefix " $\mathrm{Ba}$ " (BaTlhaping), both to be linguistically accurate and for alliterative effect; here and in the rest of the article I revert to the scholarly convention of omitting the prefix (Tlhaping).

13. This research was made possible through the financial support of the National Research Foundation, the University of Natal Research Fund, and the Council for World Mission. I acknowledge too the contributions of participants in the African Studies Group, University of Chicago, students of the Chicago Theological Seminary, students of the School of Theology, University of Natal for their contributions to this article through our discussions. In particular I acknowledge the assistance of John Wright and Philippe Denis who have sharpened my historical sensibilities. 
But not all objects were charged with the same power, so part of my purpose in this article is to determine what power the Bible was perceived to possess.

Tobacco, along with beads and knives, were prized objects of exchange and trade, obtaining their power both from their intrinsic value to the Tlhaping (whether utilitarian or aesthetic) and the increasingly complex trade transactions the Tlhaping were participating in (Comaroff and Comaroff 1991:183-184). Guns, like tobacco, were greatly desired by the Tlhaping, but were much more difficult to extract from missionaries and traders because of their scarcity and a reluctance to arm local peoples (unless of course this suited colonial objectives). Though an object of "strange power," the power of this "most condensed source of European power"(Comaroff and Comaroff 1991:201) is easily understood. Besides the obvious killing power of the gun, possessing a gun signalled some contact or alliance with missionary-colonial forces, which association was in itself a powerful protection against attack from neighbouring groups, including other indigenous peoples and white (mainly boer) settlers (Burchell 1824/1967:376-405).

Mirrors, watches, and telescopes are more problematic with respect to determining their power. Missionaries clearly believed that these goods demonstrated the superiority of their culture and civilisation, and so they were either constantly exhibiting or consistently hiding them. While the explorer William Burchell was at pains to hide his telescope, sextant and thermometer, least the Tlhaping desire them, the missionary John Campbell regularly flashed mirrors and watches in the faces of the Tlhaping leadership. While Burchell was worried that the power of these instruments would not be properly understood by the Tlhaping, Campbell hoped fervently that their power would transform the Thaping (Comaroff and Comaroff 1991:185). Common to all of these items was glass, a commodity "taken to be the window into a new way of seeing and being" (Comaroff and Comaroff 1991:185); in the Enlightenment self-conceptions of the missionaries "seeing is believing" (Comaroff and Comaroff 1991:186). Telescopes and pocket compasses were indispensable instruments with which to survey, civilise, and incorporate the uncharted and chaotic African landscape and peoples, and mirrors both literally and metaphorically showed the heathen "their own likeness in all its imperfection" (Comaroff and Comaroff 1991:186, see also 170-197). But quite what the Tlhaping made of these items is less clear from the missionary record. Most missionaries and travellers assumed, like former generations of slave traders, that the "child-like" Africans were drawn to shiny objects. Some, however, were more insightful, recognising that not only was utility highly valued in itself - the Tlhaping were particularly interested in candles and metal-working tools - but that utility was also more connected with beauty for Africans than it was for Europeans (Comaroff and Comaroff 1991:184). What is certain is that "none of these objects was introduced into a void, and while they brought novel values into the Tswana world, they also acquired meanings different from those intended by their donors" (Comaroff and Comaroff 1991:184).

But what of the Bible? What power was it perceived to wield, and what meanings did it acquire that were different from those intended by those who brought it among the Tlhaping? We catch glimpses, I will argue, of Tlhaping apprehensions of the Bible in the missionary record. I am of course aware that I am here relying on missionary documentation and therefore on missionary narrative constructions of such encounters, but socially engaged biblical scholars (and anthropologists) ${ }^{14}$ have become adept at "reading against the grain," particularly in contexts like South Africa where, Itumeleng Mosala reminds us, "the appropriation of works and events is always a contradictory process embodying in some form a "struggle"" (Mosala 1989:32). But before I turn to Tlhaping transactions with the Bible it is necessary to briefly explain my dogged focus on the Bible.

14. See (Comaroff and Comaroff 1991:xi, 171, 189). 


\section{Separating the Bible and Missionary Christianity}

Though not a common move, separating the reception of the Bible from the reception of missionary and colonial Christianity seems to be a reasonable move to make, and at least one other besides me has made it, the African-American biblical scholar Vincent Wimbush. In a series of articles Wimbush argues quite convincingly that the reception of the Bible among African slaves in America can and should be treated separately from the reception of Christianity (Wimbush 1991, 1993). I have discussed Wimbush's work at some length elsewhere (West 1999:82-86), here I allude to his work in order to observe that it is somewhat ironic that it is biblical scholars who insist on this kind of separation - the separation of the reception of the Bible from the reception of Christianity. As I observed above, other kinds of scholarly commentators on the colonial encounter tend not to distinguish between the Bible's place in indigenous people's transactions with the missionary-colonial enterprise and the place of Christianity. ${ }^{15}$ The Bible is subsumed and assumed by Christianity.

My argument here is similar, but with a twist of perspective, to that put forward by Paul Landau, when he argues that historians of religion have too readily subsumed indigenous practices into religious categories that make sense to European researchers generally and missionary Christianity in particular (Landau 1999). ${ }^{16}$ Scholars of the colonial and postcolonial, often having thoroughly mastered the master's categories and concepts, cannot perhaps be expected to make distinctions that are not made in the master narrative. For as James Barr reminds us, the Bible is analytically, in the strict philosophical sense, bound up with being Christian (Barr 1980:52). But why should the Tlhaping perceive the order of things as Barr does? My argument is that they did not (and do not). ${ }^{17}$ In the remainder of my article I provide a close reading of the journals of the explorer William Burchell in search of the Bible's presence, place, and appropriations during his visit among the Tlhaping people of southern Africa.

\section{A particular case: the Thaping}

However, before we come to Burchell, it is important to note that he was not the first to bring a Bible among the Thaping. Earlier, from 1801-1806, two missionaries made their homes in the vicinity of the Tlhaping, Jan Matthys Kok and William Edwards. With tenuous links to the Suid-Afrikaanse Sendinggenootskap (SASG), who looked after the interests of the London Missionary Society in South Africa, both Kok and Edwards attempted to do mission work among the Tlhaping. ${ }^{18}$ The record is replete with evidence of their failure to make much headway in getting the Tlhaping, under the leadership of Molehabangwe, to receive their proclamation of Christianity, though this does not mean that they did not have an impact on the Tlhaping. The obstacles they faced and the impact they may have had are well documented by Johannes du Bruyn, as are the brief sojourns of three other missionaries who worked with Kok and Edwards, Aart Anthonie van der

15. I am, however, dependent on these same studies for the otherwise thick social history they provide of this encounter. My purpose is not to duplicate their work, but to add to it by probing a particular real, but subsumed, presence.

16. I am also engaged in examining what Landau elsewhere calls the "interpretive situation" of southern Africans. How southern Africans read the Bible is "surely an interesting project," and one that is central to my work over the past ten years (see Landau 1995:xxi, note 13).

17. The present place of the Bible among the Tlhaping cannot be discussed here, but there are signs that my bracket is not misplaced.

18. I draw here and in what follows on the excellent work of Johannes T du Bruyn, (du Bruyn 1982, 1989). For more cursory accounts see (Du Plessis 1911:110), and (Beck 1997). 
Lingen, Willem Koster and Lambert Jansz. But as I have already made abundantly clear, my particular interest is in the presence of the Bible, and in this respect du Bruyn's work is less illuminating.

With these preliminary comments, we come, then, to William Burchell's visit, some six years later, with little understanding of how the Bible may have been perceived among the Tlhaping. With Burchell's visit the link between the Bible and the letter will become clearer, as will the link between the Bible and the gun, the Bible and power, and the Bible and public morality. Was the Bible simply one more object of trade, or was it an object of stranger power? Burchell's stay, to which we now turn, will certainly have something to say in contributing to and in clarifying emerging constellations of meaning.

Someone who had no formal commitment to Christian mission, but who did bring a Bible among the Tlhaping, is the explorer William Burchell. Intrepid explorer that he was, his wagons rolled into Dithakong on $13^{\text {th }}$ July 1812. Burchell's ostensible purpose for being there, as he communicates it to Chief Mothibi, is quite different from the missionaries who preceded him and followed him. The object of his visit, he says,

was to form an acquaintance with him [Mothibi] and his people, whom I had heard so favorably spoken of at Kárrikammã (Klaarwater): that so much had been said in praise of Litakun [Dithakong], that I had been very desirous of seeing his town; that I wished at the same time to hunt the wild animals, that I might be enabled to take home the skins of them to my own country; that I intended to stop with the Bachãpins long enough to learn their language, so that I might be able to tell them myself many things which I wished them to know, and that we might by these means understand each other's sentiments more clearly than they could be explained through an interpreter: and that I hoped we should thus become true friends, that I might at my return home, report of the Bachapins that they were a good people, and that on hearing this, other white-men would visit him and bring abundance of beads and tobacco (Burchell 1824:365, reprinted 1967). ${ }^{19}$

Burchell then asked Mothibi "whether he thought that what I had said, was good; and whether he approved of my remaining a long time at Litakun" (Burchell 1824/1967:365). Avoiding commenting on the substance of Burchell's speech, Mothibi indicates through the interpreter that "I was at liberty to stay as long as it pleased me, or to depart whenever I chose" (Burchell 1824/1967:366).

As it turns out, Burchell stayed not quite a month, leaving Dithakong on the $3^{\text {rd }}$ of August 1812, hardly enough time to learn the local language and converse in an unmediated manner. But Burchell did cram an awful lot into his three weeks, and his journal is extensive and full of all sorts of observations. My interest, however, is less in his observations, instructive as they are in what they tell of the European gaze and more in trying to interpret what meanings Burchell and his goods of strange power, particularly the Bible, may have acquired in the eyes of the Tlhaping.

Burchell notes, repeatedly, that the Tlhaping are observing him. Following the "interview" with Mothibi recounted briefly above, Burchell goes on to record that "The surrounding multitude were in the highest degree attentive to all we said; the eyes of every individual were fixed upon me, and examined me with utmost curiosity" (Burchell 1824/1967:366). Later, having been gazed at length by a "curious good-humoured crowd," he recognises that Mothibi and others from the Tlhaping leadership come to his wagon with "no other object than that of

19. These shifts of point of view within a sentence are deliberate, a reminder of the multiple levels of representation present. 
mere curiosity" (Burchell 1824/1967:369).

It is during this visit to his wagon that the first significant encounter with writing and text takes place. Burchell's Bible is not as prominent as Campbell's, but in his visit we already see something of an association being formed between writing, text, book and Bible. Burchell takes out his vocabulary list and reads various sentences to them in their own language, sentences that he has gathered from his guide and interpreter "Muchunka."20 Though both amused and pleased by his efforts, Burchell is surprised by how little surprise they show at this use of text, but puts this down to the fact that they "could scarcely be quite ignorant of the nature and use of books and writing, as several white-persons, had at different times, visited their country" (Burchell 1824/1967:369-370). Importantly, perhaps, there appears to be more Tlhaping interest in text during Campbell's visit, an indication, perhaps, that Burchell's use of text generated Tlhaping interest.

However, what really interested Mothibi and his advisers at this point was not the text but the gun. This becomes clear later the same day, when Burchell recognises that much of what has transpired in his conversations with Mothibi has been a prelude, "an introduction to another more important subject which it seems, had occupied their thoughts long before my arrival, and had been a matter of national consultation"- namely, the procurement of guns (Burchell 1824/1967:376). In fact, the whole of Burchell's visit is dominated by Mothibi's determination to get a gun from Burchell, and despite being bested, Burchell tells this story with a real feel for the intricacies and urgency of the acquisition. Finally, Mothibi succeeds, outmanoeuvring Burchell and obtaining a gun (Burchell 1824/1967:376-405).

But the Bible, not the gun, is my concern, notwithstanding that the gun and the Bible are closely associated, even collocated, in indigenous apprehensions of missionaries. And while Burchell is watched and studied for how a gun may be prised from his grasp, other things, including the Bible, will have been noticed and become cause for reflection. It was not only Burchell who "beheld every where, a harvest of new ideas;" and moreover, while Burchell lamented that he "was working alone in so extensive a field [of new ideas], ... where so many eyes were wanted to observe, and so many hands to record" (Burchell 1824/1967:379), the Tlhaping did not have this limitation. They had plenty enough eyes and hands.

The next day, only his second in Dithakong, Burchell again takes up text, this time in the form of writing rather than reading. The situation in which he does so is worth recording in some detail, signifying as it does potentially important aspects of text. Seated in the front part of his wagon, Burchell has a constant stream of visitors who sit beside him, "indulging their inquisitiveness in examining with their eyes every thing within my sittingplace." Burchell is tolerant of this, recognising that his two wagons are "loaded with goods of the most extraordinary kind" (Burchell 1824/1967:390). But ever the giver as well as the gatherer of information, as are most European travellers, Burchell decides to "amuse them" by taking out his journal "to record a few facts and occurrences as they passed." "Whenever I wrote, the spectators watched the motion of my hand with great attentiveness, and several of them evidently comprehended the nature and intention of what I was doing" (Burchell 1824/1967:391). Writing, it would seem, was not wholly unknown to the Tlhaping.

Writing, it would also seem, connotated concealment, for what really held the attention of the attendant Tlhaping was literally what lay behind the writing. They were intrigued, Burchell tells us about "what was concealed behind the canvas partition which parted off the sleeping-place from that end of the waggon at which we were sitting." And "although it

20. The role of indigenous agents, like "Muchunka," was clearly central to indigenous understandings of travellers like Burchell and missionaries like Campbell. He could talk directly to the Tlhaping, and they would have used him as a constant guide to what they were encountering. 
was explained to them that it was the place where I slept, and that there was nothing in it but my bedding, they would hardly believe me till some of them had taken a peep behind the curtain" (Burchell 1824/1967:391). The Tlhaping probing was obviously well founded, for, as Burchell goes on to admit, he did keep certain things hidden. There are even indications, as we will see, that writing prompted the Tlhaping to probe behind the curtain.

That writing and secrecy may have been associated in the perceptions of the Thaping is suggested by Burchell's narrative at this point, for he states (condescendingly) that "When they had seen enough of writing to give them as clear a notion of it as they were capable of, several, and more particularly Mollemmi, became very desirous of knowing what was concealed behind the canvas partition which parted off the sleeping-place from that end of the waggon at which we were sitting" (Burchell 1824/1967:391). Realising that his concealed space behind the canvas curtain "would be examined," he "had taken care at night to put into the chests upon which my bedding lay, every thing which they were likely to covet, or which might excite particular attention." On this occasion "Little therefore was visible but such objects as were familiar, or well-known, to them; unless it was some few articles of which I could not avoid making open use." Unable to resist addressing his implied readers explicitly, Burchell goes on immediately to comment:

Similar precautions are of the highest importance to a European traveller in these countries; but they require at the same time, to be so managed as not to excite any suspicion of concealment; as such suspicion might in some cases be more dangerous than an open exposure of every thing; because, when once raised, it generally leads the natives to imagine more riches to be concealed, than there are in reality (Burchell 1824/1967:391).

So what objects did Burchell conceal in his chests behind the canvas partition in his wagon? Watches, optical, mathematical, and astronomical instruments, like telescope, sextant and thermometer seem to have been the objects Burchell was concerned to conceal (Burchell 1824/1967:496, 498-499, 509), because, he says on a number of occasions in his narrative, "the glittering appearance of which might excite in savages the desire of possessing them" (Burchell 1824/1967:577; 1824/1967:498-499). In an entry recorded the day after he allows the Tlhaping to inspect his partitioned place, Burchell reveals something else that was hidden here, not so much an object as an activity: journal writing.

It was only by a stratagem that time could be found for writing my journal; - I ordered my people to keep all strangers away from my waggon, by telling them that I had been much fatigued, and that, until I made my appearance in public and the waggon was thrown open, they were always to suppose that I was then asleep and must not be disturbed. In the mean time, I was busily employed in writing in my sleeping-place, the only part where I could keep myself undiscovered (Burchell 1824/1967:401).

But, as Burchell himself acknowledges, "Mattivi and several of the chieftains were cunning enough to suspect that it might be only a trick to keep myself alone; and they therefore, as they walked by the end of the wagon, peeped in to ascertain the truth" (Burchell 1824/1967:401). The truth was, of course, that Burchell was in there writing, but, he maintains, "when they saw that I was not in my sitting-room, they concluded that I was still really asleep, especially as I took the utmost care not to make the least noise, nor by any movement, to cause the wagon to shake" (Burchell 1824/1967:401-402). Were Mothibi and his men so easily fooled? I think not. The constant surveillance of the Tlhaping missed very little. Only the day before, Burchell had recorded in his journal how difficult it was to conceal objects and actions from the Tlhaping. Reflecting on an incident in which some of his men deserted him and his oxen and sheep out of their fear of the Tlhaping, Burchell laments, "This affair [the desertion of his men], in spite of our wish to conceal it, was soon 
made known to the Chief and the whole town" (Burchell 1824/1967:385). The circumstances and the incessant scrutiny of the Thaping made concealment difficult.

Why would Burchell, from the perspective of the Tlhaping, openly read from his writings (Burchell 1824/1967:369), ostentatiously and publicly write in his journal (Burchell 1824/1967:391), but also hide in the back of his wagon in order to spend long hours writing? Were there perhaps different kinds of writing and different kinds of text? Were some forms of writing and text more powerful and therefore purposefully concealed and controlled? These and other related questions must have permeated Tlhaping thinking, and must have laid some sort of foundation for the missionaries who were to engage with them, and text, more protractedly.

But before we come to that, what of Burchell's Bible, for he definitely had one? It is perhaps appropriate to note that the first foreshadowing we find of Burchell's Bible comes in his journal entry a few days after Mothibi's successful acquisition of one of his guns. While Burchell is rather peeved at "the success of their cunning" in obtaining a gun through "so flagrant an act of bad faith" in using the pretext of wanting to fire one of his guns as a means of taking hold (literally) of a gun, he is realistic, recognising that not only is he "completely in their power and that my gun was irrecoverably gone," but that the desire for the gun came from the wider context in which he and they found themselves (Burchell 1824/1967:405). The gun was an important part of an emerging collocation of goods of power. The journal entry three days later, the $17^{\text {th }}$ of July, provides an example of another emerging collocation, a collocation that may have included the Bible.

Being a Sunday, Burchell sets out quite deliberately to establish "a connection of ideas."

This being Sunday, my flag was hoisted upon a tall bamboo-cane and fixed at the hinder part of my waggon, conformably to a regulation which we followed while beyond the boundary of the Cape colony. This practice was of considerable utility, in dividing our time, and in assisting the Hottentots in keeping an account of the days of the week. By having this object before their eyes for twelve hours, a connection of ideas was established between the flag and every occurrence which took place on that day, as well as between that and the station at which it was hoisted. We were thus enabled more easily to recollect the place at which, or the day when, it was Sunday, and consequently to keep check upon mistakes in our reckoning (Burchell 1824/1967:425).

These signs, as Burchell so clearly articulates, were not only meant to guide wandering Englishmen in a strange land, but to establish new signposts for reconstructing African ways. Among the ideas Burchell intended to connect with the flag was Sunday as a day of rest (Burchell 1824/1967:426). What he did not anticipate, though he was pleased to have his day of rest interrupted for this purpose (Burchell 1824/1967:426), was that a delegation of the Tlhaping came to his wagon and wanted to know about prayer. "Muchunka" had explained to his fellow Tlhaping that "it was the custom at Klaarwater to do nothing on that day, excepting to say prayers." They now "wished to know what prayers were" (Burchell 1824/1967:426).

Why they should ask this question is not clear. Perhaps this is one of the activities the Tlhaping imagined taking place in secret in Burchell's hiding place - the "hinder" hidden and partitioned portion of his wagon - marked on Sundays with the English flag! Again, Burchell's sense of how these signs collocated and Tlhaping perceptions of these same signs were not necessarily the same. Ever eager to instruct - to give "some new and better ideas" - Burchell told them "of our notions respecting the Deity; of the absolute necessity of a virtuous life; and of the preservation of good-faith between man and man, and between nation and nation" (Burchell 1824/1967:427-428). Of course, Burchell is as interested in 
gratifying his own curiosity as to their "knowledge and conceptions of the Divinity" as he is in imparting "some new and better ideas" (Burchell 1824/1967:427). He is also intensely interested in how the Tlhaping respond to "this mode of argument and explanation" (Burchell 1824/1967:428), and his finding (for he was conducting research) was that had the object of my visit to Litákun been such as it may be supposed that of a missionary would be, I think I should have found it not impossible to have gained over their minds an ascendancy, which, with a little management, might have been rendered useful in disposing them for the reception and adoption of the purer principles of religion (Burchell 1824/1967:428-429). ${ }^{21}$

Continuing, and here we get a glimpse of Burchell's view of missionaries, he goes on to say: "It is by making the untutored savage see and feel the advantage of a virtuous life, that he can be taught to submit to its rules. Where this is not done, the missionary will labour all his life, to no purpose but to cheat himself" (Burchell 1824/1967:429).

Interestingly, the conversation then does shift to the flag, providing yet more opportunity for Burchell to elaborate on his understanding of how ideas of flag, rationality, language and nation might be connected (Burchell 1824/1967:429-430). But note, prayer has now been added to the ideas circulating, and not by Burchell. So, I want to suggest, unexpected collocations may have been emerging. Secret writings, hidden places, texts, flags, and prayers may have begun to form associations among the Tlhaping not anticipated or even imagined by Burchell.

Later on the same day, Mothibi too comes to Burchell, drawn by Burchell's flag, it would seem, but making inquiries about Burchell's writing "some Sichuana words." Mothibi asks "if I did it that I might learn them when I returned to my own country," but is told by Burchell that "it was done that others might learn them also and come to Litákun" (Burchell 1824/1967:430-431). With this remark, Burchell linked himself, and all his signs, to those who would follow him. Among these signs may have been Burchell's Bible, to which we are coming closer.

Some days after these discussions about prayer, days in which Burchell introduced yet another use for text - a place in which portraits of the Tlhaping, and their environs, could be represented (Burchell 1824/1967:463, see also 481, 486) - the Bible is overtly used by Burchell. The occasion for the Bible's appearance and its use are of enormous importance, establishing as they do clues to the white-man's connection of ideas about the Bible. Van Roye, one of Burchell's hired "Hottentots," had consistently shown disrespect and open defiance to Burchell, refusing to obey legitimate orders.

It became therefore unavoidable, to take serious notice of his conduct; and I immediately ordered all my men to be present at the waggons, and declared that it was now my intention to punish his disobedience; but that I would first hear, in the presence of all, what he had to say in his defence (Burchell 1824/1967:468).

Among those present, besides Burchell's immediate party, were "Mattīi and his chieftains, whose whole attention was fixed on us." Intently observing, Mothibi and the other Tlhaping leadership "were sitting at a little distance: not a word was spoken by any one; nor was the least sound to be heard in the mootsi. Neither the Chief, nor any of the natives, attempted to interfere with these transactions; nor did they make the smallest remark: all were serious and still" (Burchell 1824/1967:468). Mixing his own and local indigenous signs, and thereby forging novel connections of ideas, Burchell conducts a formal trial of Van Roye at the wagons in Mothibi's "mootsi." Having laid out his pistols and sword on

21. Burchell is of the opinion that the Tlhaping are atheists (Burchell 1824/1967:444). 
the chest in his wagon - more signs for the Tlhaping to conjure with (Smith 1994) - "to impress more strongly on my people the serious nature of the affair" (Burchell 1824/1967:468) he then "produced a Dutch Testament, and as Van Roye could read tolerably well, I bade him take notice what book it was" (Burchell 1824/1967:470). "With some formality" Burchell uses the Bible in order to administer "the usual oath to relate the truth." However, the prevarications of Van Roye push him to expound on the oath-taking ritual just enacted:

Seeing this, I admonished him of the dreadful crime which he would commit by uttering a falsity at the moment when he called God to witness his veracity: I explained to him in the most solemn and impressive manner, the respect which he as a Christian ought to show to that book; and that it was better he should at once condemn himself by confessing his fault in the presence of his companions, than by prevarication and wilful misrepresentation, pronounce his own condemnation in the presence of God, to whom all our actions and thoughts were known (Burchell 1824/1967:470).

Sensing that these admonitions had "had their proper effect upon him" and that "a few words more would decide him to confess that he was blameable" (Burchell 1824/1967:470), Burchell reiterates his use of the Bible as symbol by asking Van Roye to once again "lay his hand on the book," but this time only "after repeating to him the substance of several passages in the New Testament" (Burchell 1824/1967:471). These acts and exhortations had the desired effect, and Van Roye confessed that his conduct had not been "influenced by the spirit of obedience which that book taught and commanded a servant to show to a master" (Burchell 1824/1967:471).

His own men, Burchell writes in his journal, "had received a useful lesson" (Burchell 1824/ 1967:471); but what lesson had Mothibi and the Tlhaping learned? Unusually, Burchell is so consumed with establishing his authority among his own men that he neglects to comment on the impact of this incident on those sitting "at a little distance," those "whose whole attention was fixed on" the proceedings. Those who sat silently watching would have seen remarkable things. They would have seen the Bible used both as a closed object of power and as an opened object with particular things to say. As a closed object the Bible could be used by someone who controlled it to compel others to speak the truth and do their bidding; as an opened object the Bible contained knowledge that was of use in a context of contestation. The Bible, it would seem, shared certain features with the sword and the pistol. Clearly these and a whole host of connections of ideas were set in motion by Burchell's use of the Bible. The Bible was now one more idea/object with which the Tlhaping had to transact, and transact they would, for this was clearly a significant item/object of power. Furthermore, whatever the associations and collocations of these signs in the perceptions of the Tlhaping, and my analysis is suggestive rather than definitive, they would have formed the foundation of their biblical interpretation for when next they encountered the Bible.

I wonder too where Burchell kept his Bible. Did he keep it in public view, or was it to be found among his telescope, sextant and thermometer, "the glittering appearance of which might excite in savages the desire of possessing them?" (Burchell 1824/1967:577). Burchell never, according to his record, offers the Bible to the Tlhaping; this would be the task of those who came after him. And yet his visit lays a foundation of signs, and possible connections between these signs, to which the missionaries who came next would build. But, as we have observed, the Tlhaping would make their own connections and construct their own meanings. Clearly the Bible was an object of strange power; this had been demonstrated by Burchell. But was it of any potential use to the Tlhaping? With this 
question in mind we would move on, if we had the space here to continue with the task of writing an interpretative history of the Bible among this southern African people, waiting among the Tlhaping for the missionaries who were on their way.

\section{Conclusion}

But for the purposes of this article we will leave the Tlhaping here, before even the missionaries arrive for an extended stay (see West 2002). The descriptive detail and cautious analysis demonstrates the complexity of the task, but we dare not refuse the task just because it is demanding.

Is the Bible a substantive resource in the realm of public morality in South Africa, or is it merely the legacy of a public transcript that is slowly being put aside by the (previously) dominated as the (previous) forces of domination continue to loose their powers of surveillance and control? My research would seem to indicate that the Bible plays a significant and substantive role in our South African realities, though not perhaps the role we have imagined. Only a thoroughly descriptive interpretative history of the Bible, a task that will demand the use of emic categories and fresh forms of analysis, will suffice if we are to fathom the Bible's place in our public morality.

Marxism, I would suggest, though retaining (and perhaps gaining) some analytical presence and power in our society, is not a primary resource in forging and sustaining our popular public morality. African Traditional Religions certainly plays a significant role, though it would seem from the public transcript, almost always in some form of alliance with the Bible and African Christianities. But whether this alliance is substantive or merely the residue of a fading public transcript awaits further analysis, though I would anticipate the former.

Also awaiting further analysis is the contribution of other candidates as silos for our public morality. Globalisation is producing a host of related artefacts and consumables that probably play a larger role in forging and sustaining our public morality than we would like to admit. ${ }^{22}$ But I will leave that analysis to others. My task remains to make sense of the Bible's presence and place among us, and that includes its role in our public morality.

\section{BIBLIOGRAPHY}

Bailey, Randall C 1998. The danger of ignoring one's own cultural bias in interpreting the text. In The Bible and postcolonialism, edited by RS Sugirtharajah. Sheffield: Sheffield Academic Press.

Barr, James 1980. The scope and authority of the Bible. London: SCM.

Beck, Roger B 1997. Monarchs and missionaries among the Tswana and Sotho. In: Christianity in South Africa: a political, social, and cultural history, edited by R Elphick and R Davenport. Berkeley: University of California Press.

Bediako, Kwame 1995. Christianity in Africa: the renewal of a non-western religion. Edinburgh and Maryknoll, NY: Edinburgh University and Orbis.

Boesak, Allan 1984. Black and Reformed: apartheid, liberation, and the Calvinist tradition. Johannesburg: Skotaville.

Burchell, William J 1824 (Reprint, 1967). Travels in the interior of Southern Africa. With a new Introduction by A. Gordon-Brown ed. Vol. 2. London (Reprint, Cape Town):

22. We may call this "market morality." 
Longman, Hurst, Rees, Orme, Brown, and Green (Reprint, C Struik).

1824 (Reprint, 1967). Travels in the interior of Southern Africa. With a new Introduction by A. Gordon-Brown ed. Vol. 1. London (Reprint, Cape Town): Longman, Hurst, Rees, Orme, Brown, and Green (Reprint, C Struik).

Cady, LE 1986. Hermeneutics and tradition: the role of the past in jurisprudence and theology. Harvard Theological Journal 79:439-463.

Chikane, Frank 1985. The incarnation in the life of the people in Southern Africa. Journal of Theology for Southern Africa 51:37-50.

Comaroff, Jean 1985. Body of power, spirit of resistance: the culture and history of a South African people. Chicago: University of Chicago Press.

Comaroff, Jean \& Comaroff, John L 1991. Of revelation and revolution: Christianity, colonialism and consciousness in South Africa. Vol. 1. Chicago: University of Chicago Press.

Comaroff, John L \& Comaroff, Jean 1997. Of revelation and revolution: the dialectics of modernity on a South African frontier. Vol. 2. Chicago: University of Chicago Press.

De Gruchy, John W 1985. Christians in conflict: the social reality of the South African Church. Journal of Theology for Southern Africa 51:16-26. 1985. Editorial. Journal of Theology for Southern Africa 51:3-4.

Du Bruyn, Johannes T 1982. Die Tlhaping en die eerste sendelinge, 1801-1806. South African Historical Journal 14:8-34. 1989. Die aanvangsjare van dir Christelike sending onder die Tlhaping, 1800-1825. Pretoria: Die Staatsdrukker.

Du Plessis, Johannes 1911. A history of Christian mission in South Africa. London: Longmans, Green and Co.

Dube, Musa W 1996. Reading for decolonization (John 4: 1-42). Semeia 75:37-59. 1997. Toward a postcolonial feminist interpretation of the Bible. Semeia 78:11-26. 1999. Consuming a colonial time bomb: translating badimo into "demons" in the Setswana Bible (Matthew 8:28-34; 15:2; 10:8). Journal for the Study of the New Testament 73:33-59. 2000. Postcolonial feminist interpretation of the Bible. St. Louis: Chalice Press.

Landau, Paul 1999. "Religion" and Christian conversion in African history: a new model. Journal of Religious History 23 (1):8-30.

Landau, Paul Stuart 1995. The realm of the Word: language, gender, and Christianity in a Southern African kingdom. Portsmouth: Heinemann.

Maimela, Simon 1991. Black Theology and the quest for a God of liberation. In Theology at the end of modernity: essays in honor of Gordon D. Kaufman, edited by SG Devaney. Philadelphia: Trinity Press.

Maluleke, Tinyiko S 1996. Black and African theologies in the New World Order: a time to drink from our own wells. Journal of Theology for Southern Africa 96:3-19. 1997. Half a century of African Christian theologies: elements of the emerging agenda for the twenty-first century. Journal of Theology for Southern Africa 99:4-23.

1998. African Traditional Religions in Christian mission and Christian scholarship: re-opening a debate that never started. Religion and Theology 5:121-137. 1998. Black theology as public discourse. In Constructing a language of religion in public life: Multi-Event 1999 Academic Workshop papers, edited by JR Cochrane. Cape Town: University of Cape Town. 
2000. The Bible among African Christians: a missiological perspective. In To cast fire upon the earth: Bible and mission collaborating in today's multicultural global context, edited by T Okure. Pietermaritzburg: Cluster Publications.

Masenya, Madipoane 1997. Proverbs 31:10-31 in a South African context: a reading for the liberation of African (Northern Sotho) women. Semeia 78:55-68.

Masipa, Lekoapa Patrick 1997. The use of the Bible in Black Theology, with reference to the story of Exodus. Master of Theology, School of Theology, University of Natal, Pietermaritzburg.

Mbiti, John S 1977. The biblical basis for present trends in African theology. In African theology en route: papers from the Pan-African conference of Third World theologians, Accra, December 1977, edited by K Appiah-Kubi and S Torres. Maryknoll, NY: Orbis.

Mbuwayesango, Dora Rudo 1997. Childlessness and women-to-women relationships in Genesis and in African patriarchal society: Sarah and Hagar from a Zimbabwean woman's perspective (Gen 16:1-16; 21:8-21). Semeia 78:27-36.

Mofokeng, T 1988. Black Christians, the Bible and liberation. Journal of Black Theology 2:34-42.

Mosala, Itumeleng J 1986. The relevance of African Traditional Religions and their challenge to Black Theology. In The unquestionable right to be free: Essays in Black Theology, edited by IJ Mosala and B Tlhagale. Johannesburg: Skotaville. 1986. The use of the Bible in Black Theology. In The unquestionable right to be free: essays in black theology, edited by IJ Mosala and B Tlhagale. Johannesburg: Skotaville. 1987. Biblical hermeneutics and black theology in South Africa. PhD, University of Cape Town, Cape Town. 1989. Biblical hermeneutics and black theology in South Africa. Grand Rapids: Eerdmans.

Oduyoye, Mercy Amba 1995. Daughters of Anowa: African women and patriarchy. Maryknoll, NY: Orbis.

Sanneh, Lamin 1989. Translating the message: the missionary impact on culture. Maryknoll, NY: Orbis.

Scofield, Rodney 1985. A report: the forum on Christianity in the Southern African context. Journal of Theology for Southern Africa 51:51-54.

Scott, James C 1990. Domination and the arts of resistance: hidden transcripts. New Haven and London: Yale University Press.

Setiloane, Gabriel 1977. Where are we in African Theology? In African Theology en route: papers from the Pan-African Conference of Third World Theologians, Accra, December 17-23, 1977, edited by K Appiah-Kubi and S Torres. Maryknoll, NY: Orbis.

Sibeko, Malika \& Haddad, Beverley G 1997. Reading the Bible "with" women in poor and marginalized communities in South Africa (Mark 5:21-6:1). Semeia 78:83-92.

Smith, Theophus H 1994. Conjuring culture: biblical formations of black America. Oxford and New York: Oxford University Press.

Tlhagale, Buti 1985. Culture in an apartheid society. Journal of Theology for Southern Africa 51:27-36.

Tutu, Desmond Mpilo 1983. Hope and suffering: sermons and speeches. Johannesburg: Skotaville. 
West, Gerald O 1997. Finding a place among the posts for post-colonial criticism in biblical studies in South Africa. Old Testament Essays 10:322-342.

1999. The academy of the poor: towards a dialogical reading of the Bible. Sheffield: Sheffield Academic Press.

2000. Mapping African biblical interpretation: a tentative sketch. In The Bible in Africa: transactions, trends and trajectories, edited by GO West and MW Dube. Leiden: E.J. Brill.

2002. The Bible as bola: among the foundations of African biblical apprehensions. Journal of Theology for Southern Africa 112:23-37.

-Forthcoming. The Bible as bola, and biblical interpretation as marabi: Tlhaping transactions with the Bible. In Script, subjugation and subversion: essays in orality, literacy and colonialism in antiquity and modern Africa, edited by JA Draper. Pietermaritzburg: Natal University Press.

Forthcoming. Redirecting the direction of travel: discerning signs of a neoindigenous Southern African biblical hermeneutics. In Redirected travel: alternative journeys and places in biblical studies, edited by R Boer and E Conrad. Sheffield: Continuum/Sheffield Academic Press.

Wimbush, Vincent L 1991. The Bible and African Americans: an outline of an interpretative history. In Stony the road we trod: African American biblical interpretation, edited by C. H. Felder. Minneapolis: Fortress.

1993. Reading texts through worlds, worlds through texts. Semeia 62:129-140. 